Araştırma Makalesi / Research Article

Elektrik Elektronik Mühendisliği /

Electrical Electronics Engineering
Iğdır Üniversitesi Fen Bilimleri Enstitüsü Dergisi, 10(1): 128-140, 2020

Journal of the Institute of Science and Technology, 10(1): 128-140, 2020

\title{
Proportional-Integral Controller Design for Thermal Systems
}

\author{
Bilal ŞENOL ${ }^{1}$, Uğur DEMİROĞLU ${ }^{2}$
}

\begin{abstract}
This study proposes to tune proportional integral (PI) controllers for the stability and performance of thermal processes described by first order plus time delay (FOPTD) and second order plus time delay (SOPTD) plants. In addition to stability, parameters of the controllers are tuned to meet the desired gain crossover frequency and phase margin for each system. Design schemes of the controllers are clearly given and the results are applied on some plants provided from the literature. Illustrative examples are given to prove the method.
\end{abstract}

Keywords: Proportional integral controller, thermal systems, first order, second order, plus time delay.

\section{Termal Sistemler için Oransal-Integral Denetleyici Tasarımı}

ÖZET: Bu çalışmada birinci derece zaman gecikmeli (FOPTD) ve ikinci derece zaman gecikmeli (SOPTD) modellerle ifade edilen termal sistemlerin kararlılık ve performansı için oransal integral (PI) denetleyicilerin elde edileme yöntemi önerilmiştir. Kararlılığa ek olarak, denetleyici parametreleri her bir sistem için arzu edilen kazanç kesim frekansı ve faz payı özelliklerini sağlamak üzere ayarlanmıştır. Denetleyici tasarım şeması açıkça verilmiştir ve sonuçlar literatürden elde edilmiş bazı modeller üzerinde uygulanmıştır. Yöntemi kanıtlamak için görsel örnekler verilmiştir.

Anahtar Kelimeler: Oransal integral denetleyici, termal system, birinci derece, ikinci derece, zaman gecikmeli.

\footnotetext{
${ }^{1}$ Bilal ŞENOL (Orcid ID: 0000-0002-3734-8807), İnönü Üniversitesi, Mühendislik Fakültesi, Bilgisayar Mühendisliği Bölümü, Malatya, Türkiye

${ }^{2}$ Uğur DEMİROĞLU (Orcid ID: 0000-0002-0000-8411), Firat Üniversitesi, Bilgi İşlem Dairesi, Elazığ, Türkiye

*Sorumlu Yazar/Corresponding Author: Bilal ŞENOL, e-mail: bilal.senol@inonu.edu.tr
}

Geliș tarihi / Received: 02-05-2019

Kabul tarihi / Accepted: 04-12-2019 


\section{INTRODUCTION}

Thermal systems have many areas of implementation such as heat exchangers (Vasičkaninová and Bakošová, 2016; Vasičkaninová and M. Bakošová, 2012; Bakošová and J. Oravec, 2014), air conditioning (Khayyam, 2013), waste recovery (Peralez et al., 2012; Hernandez et al., 2017), power systems (Powell et al., 2017), automotive (Sharif et al., 2016), modeling (Gabano and Poinot, 2011) etc. and therefore, their control is an important issue (Jaluria, 2007). As for other processes, stability of thermal systems can be denoted as the most significant matter.

Stability of thermal systems is investigated by numerous studies in the literature. For instance, a paper related to thermal stability of phase change materials is presented in (Rathod and Banerjee, 2013). Stability of SiC nanofluids is investigated in (Chen et al., 2017) and thermal stability of ionic liquidbased nanofluids is studied in (Liu et al., 2014). Ilyas et al. investigated the stability, rheology and thermal analysis of advanced cooling systems in (Ilyas et al., 2017). System operation stability of an organic ranking cycle is presented in (Hu et al, 2017). Thermal stability of specialized solar cells is implemented in (Zhao et al., 2016) and thermal stability of GaAs solar cells is practiced in (Sun et al., 2017). Robust stability of thermal systems is illustratively analyzed in (Matušů and Pekař, 2017) etc.

In recent studies, thermal systems are described by various models. This paper deals with thermal systems expressed with first order plus time delay (FOPTD) and second order plus time delay (SOPTD) transfer functions. Rashid et al. studied the performance analysis for a FOPTD thermal system in (Rashid et al., 2017). An artificial intelligence approach for FOPTD and SOPTD heat exchanger control can be found in (Jamal and Syahputra, 2016). A paper for various controller methodologies for FOPTD heat exchangers is given in (Pawar et al., 2015) and temperature control of a thermal plant described by FOPTD transfer function is presented in (Padhee, 2014). Robust stability of a FOPTD heat exchanger is studied in (Vasičkaninová and Bakošová, 2016). A study related to fractional order implementation of a FOPTD thermal plant is in (Macias and Sierociuk, 2012) and control of temperature uniformity is realized in (He et al., 2014).

Stability of systems are mostly ensured by controllers thus various types of controllers are implemented for the stability of various types of plants. As a form of the PID controller, this paper is interested in PI controllers which is widely used in industrial processes thus, tuning of PI controller parameters is a critical issue. There can be listed numerous studies on PI tuning in the literature. For instance, Miao et al. optimized PI parameters for different performance criteria in (Miao et al., 2017). A comparative study of cascaded PI-PD controllers applied on a coupled tank system can be found in (Kar and Roy, 2018). Onat et al. presented a PI tuning method for FOPTD plants in (Onat et al., 2012). Studies on the similar direction to this paper can also be found. (Fung et al., 1998; Ho et al., 1995; Cokmez et al., 2018). Main contribution of the method in this paper from existing studies is the direct analytical approach to calculate the controller parameters. The parameters are obtained analytically, with no iterations.

This paper is focused on parameter tuning of PI controllers for the stability and performance of thermal plants described by FOPTD and SOPTD transfer functions. PI controller is tuned considering some gain crossover frequency and phase margin requirements. Gain and phase specifications are inspired from Bode's ideal transfer function (Barbosa et al., 2004). PI controller design for both FOPTD and SOPTD plants are explicated and the results are illustratively given.

Organization of this paper is as follows. Section II briefly represents PI controllers and FOPTD and SOPTD plants. Design procedure of PI controllers is clarified in section III. Section IV gives illustrative examples and conclusions are in section $\mathrm{V}$. 


\section{MATERIALS AND METHODS}

The system to be controlled in this paper is illustrated in Fig. 1.

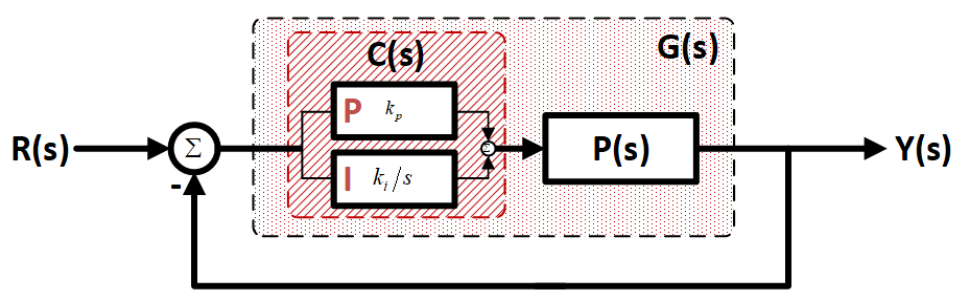

Fig. 1. Diagram of the closed loop system.

Considering Fig. 1, system transfer function and its frequency response can be written in the following forms.

$$
\begin{aligned}
& G(s)=C(s) P(s) \\
& G(j \omega)=C(j \omega) P(j \omega) .
\end{aligned}
$$

This paper proposes a method to provide the following design specifications for FOPTD and SOPTD systems with PI controllers. Suppose that the phase crossover frequency of the system is $\omega_{c}$ and the phase margin is $\phi_{m}$. Then, gain specification of the system is,

$$
\left|G\left(j \omega_{c}\right)\right|=1 .
$$

Similarly, phase margin specification is,

$$
\angle G\left(j \omega_{c}\right)=\phi_{m}-\pi .
$$

Let us now define the controller and the plants. A proportional integral controller has the following notation in the literature.

$$
C(s)=k_{p}+\frac{k_{i}}{s}=\frac{k_{p} s+k_{i}}{s}
$$

Substituting $s=j \omega$ in Eq. 5, we can obtain its frequency response.

$$
C(j \omega)=k_{p}+\frac{k_{i}}{j \omega}=k_{p}-j \frac{k_{i}}{\omega}
$$

Magnitude and the phase of the controller respectively are,

$$
\begin{aligned}
& |C(j \omega)|=\sqrt{k_{p}^{2}+\left(-\frac{k_{i}}{\omega}\right)^{2}}=\sqrt{\frac{k_{i}^{2}+k_{p}^{2} \omega^{2}}{\omega^{2}}} \\
& \angle C(j \omega)=\arctan \left(\frac{-\frac{k_{i}}{\omega}}{k_{p}}\right)=-\arctan \left(\frac{k_{i}}{k_{p} \omega}\right)
\end{aligned}
$$

The reason why a PI controller is considered in this paper is that this approach is based on obtaining two frequency specifications given in Eq. 3 and Eq. 4. As the PI controller has two parameters which are $k_{p}$ and $k_{i}$, it would be convenient to solve two equations of two unknown parameters. PI controller defined above will be implemented for FOPTD and SOPTD plants in this paper. This procedure is given below.

\section{FOPTD Plants}

The first order plus time delay plant discussed in this paper is given in the following form. 


$$
P_{1}(s)=\frac{K}{T s+1} \mathrm{e}^{-L s}
$$

System transfer function can be obtained by the following notation.

$$
G_{1}(s)=C(s) P_{1}(s)
$$

Considering the gain and phase specifications in Eq. 3 and Eq. 4, following theorem is valid for the coefficients of the PI controller.

Theorem 1: Following equations of $k_{p}$ and $k_{i}$ can be used to obtain the parameters of the proportional integral controller to satisfy the gain and phase specifications for FOPTD systems.

$$
\begin{aligned}
& k_{p}= \pm \frac{\sqrt{1+T^{2} \omega_{c}^{2}}}{K \sqrt{1+\tan \left(\phi_{m}+L \omega_{c}+\arctan \left(T \omega_{c}\right)\right)^{2}}} \\
& k_{i}=\mp \frac{\omega_{c} \sqrt{1+T^{2} \omega_{c}^{2}} \tan \left(\phi_{m}+L \omega_{c}+\arctan \left(T \omega_{c}\right)\right)}{K \sqrt{1+\tan \left(\phi_{m}+L \omega_{c}+\arctan \left(T \omega_{c}\right)\right)^{2}}}
\end{aligned}
$$

Proof: Considering Eq. 9, frequency response of the FOPTD plant can be written as,

$$
\begin{aligned}
P(j \omega) & =\frac{K}{T(j \omega)+1} \mathrm{e}^{-L(j \omega)}=\frac{K}{1+j T \omega} \mathrm{e}^{-j L \omega} \\
& =|P(j \omega)| e^{j \angle P(j \omega)}=\sqrt{\frac{K}{1+T^{2} \omega^{2}}} e^{-j(\arctan (T \omega)+L \omega)}
\end{aligned} .
$$

Then, magnitude and phase of Eq. 13 are,

$$
\begin{aligned}
& \left|P_{1}(j \omega)\right|=\sqrt{\frac{K}{1+T^{2} \omega^{2}}} \\
& \angle P_{1}(j \omega)=-\arctan (T \omega)-L \omega .
\end{aligned}
$$

Considering Eq. 6 and Eq. 13, frequency response of the system can be obtained.

$$
G_{1}(j \omega)=C(j \omega) P_{1}(j \omega)
$$

Thus, magnitude and phase of the system are,

$$
\begin{aligned}
& \left|G_{1}\left(j \omega_{c}\right)\right|=\left|C\left(j \omega_{c}\right)\right|\left|P_{1}\left(j \omega_{c}\right)\right|=\sqrt{\frac{k_{i}^{2}+k_{p}^{2} \omega_{c}^{2}}{\omega_{c}^{2}}} \sqrt{\frac{K}{1+T^{2} \omega_{c}^{2}}}, \\
& \angle G_{1}\left(j \omega_{c}\right)=\angle C\left(j \omega_{c}\right)+\angle P_{1}\left(j \omega_{c}\right)=-\arctan \left(\frac{k_{i}}{k_{p} \omega_{c}}\right)-\arctan \left(T \omega_{c}\right)-L \omega_{c} .
\end{aligned}
$$

Considering the magnitude and phase specifications in Eq. 3 and Eq. $4, k_{p}$ and $k_{i}$ of the FOPI controller are found as given in Eq. 11 and Eq. 12. o

\section{SOPTD Plants}

Following description of the SOPTD plant is implemented in this paper.

$$
P_{2}(s)=\frac{K}{\left(T_{1} s+1\right)\left(T_{2} s+1\right)} \mathrm{e}^{-L s}
$$

Thus, following system is obtained.

$$
G_{2}(s)=C(s) P_{2}(s)
$$


Then, following theorem holds.

Theorem 2: Following equations of $k_{p}$ and $k_{p}$ can be used to obtain the parameters of the proportional integral controller to satisfy the gain and phase specifications for SOPTD systems.

$$
\begin{aligned}
& k_{p}= \pm \frac{\sqrt{1+T_{1}^{2} \omega_{c}^{2}} \sqrt{1+T_{2}^{2} \omega_{c}^{2}}}{K \sqrt{1+\tan \left(\phi_{m}+L \omega_{c}+\arctan \left(\frac{K\left(T_{1}+T_{2}\right) \omega_{c}}{K-K T_{1} T_{2} \omega_{c}^{2}}\right)\right)^{2}}} \\
& k_{i}=\mp \frac{\omega_{c} \sqrt{1+T_{1}^{2} \omega_{c}^{2}} \sqrt{1+T_{2}^{2} \omega_{c}^{2}} \tan \left(\phi_{m}+L \omega_{c}+\arctan \left(\frac{K\left(T_{1}+T_{2}\right) \omega_{c}}{K-K T_{1} T_{2} \omega_{c}^{2}}\right)\right)}{\left.\arctan \left(\frac{K\left(T_{1}+T_{2}\right) \omega_{c}}{K-K T_{1} T_{2} \omega_{c}^{2}}\right)\right)^{2}}
\end{aligned}
$$

Proof : According to Eq. 19, frequency response of the SOPTD plant can be written as,

$$
\begin{aligned}
P_{2}(j \omega) & =\frac{K}{\left(T_{1}(j \omega)+1\right)\left(T_{2}(j \omega)+1\right)} \mathrm{e}^{-L(j \omega)}=\frac{K}{\left(1+j T_{1} \omega\right)\left(1+j T_{2} \omega\right)} \mathrm{e}^{-j L \omega} \\
& =\left(\frac{K-K T_{1} T_{2} \omega^{2}}{\left(1+T_{1}^{2} \omega^{2}\right)\left(1+T_{2}^{2} \omega^{2}\right)}+j\left(-\frac{K\left(T_{1}+T_{2}\right) \omega}{\left(1+T_{1}^{2} \omega^{2}\right)\left(1+T_{2}^{2} \omega^{2}\right)}\right)\right) \mathrm{e}^{-j L \omega} \\
& =|P(j \omega)| e^{j L P(j \omega)}=\sqrt{\frac{K^{2}}{\left(1+T_{1}^{2} \omega^{2}\right)\left(1+T_{2}^{2} \omega^{2}\right)}} e^{-j\left(\arctan \left(\frac{K\left(T_{1}+T_{2}\right) \omega}{K-K T_{1} T_{2} \omega^{2}}\right)+L \omega\right)}
\end{aligned}
$$

Thus, magnitude and phase of the SOPTD plant is,

$$
\begin{aligned}
& |P(j \omega)|=\sqrt{\frac{K^{2}}{\left(1+T_{1}^{2} \omega^{2}\right)\left(1+T_{2}^{2} \omega^{2}\right)}} \\
& \angle P(j \omega)=-\arctan \left(\frac{K\left(T_{1}+T_{2}\right) \omega}{K-K T_{1} T_{2} \omega^{2}}\right)-L \omega
\end{aligned}
$$

Frequency response of the system with FOPI controller and the SOPTD plant is written in the following notion.

$$
G_{2}(j \omega)=C(j \omega) P_{2}(j \omega)
$$

Magnitude and phase of the system are given as follows.

$$
\begin{aligned}
& \left|G\left(j \omega_{c}\right)\right|=\left|C\left(j \omega_{c}\right)\right|\left|P\left(j \omega_{c}\right)\right|=\sqrt{\frac{k_{i}^{2}+k_{p}^{2} \omega_{c}^{2}}{\omega_{c}^{2}}} \sqrt{\frac{K^{2}}{\left(1+T_{1}^{2} \omega_{c}^{2}\right)\left(1+T_{2}^{2} \omega_{c}^{2}\right)}} \\
& \angle G\left(j \omega_{c}\right)=\angle C\left(j \omega_{c}\right)+\angle P\left(j \omega_{c}\right)=-\arctan \left(\frac{k_{i}}{k_{p} \omega_{c}}\right)-\arctan \left(\frac{K\left(T_{1}+T_{2}\right) \omega_{c}}{K-K T_{1} T_{2} \omega_{c}^{2}}\right)-L \omega_{c}
\end{aligned}
$$

Considering the magnitude and phase specifications in Eq. 3 and Eq. $4, k_{p}$ and $k_{i}$ of the FOPI controller are found as given in Eq. 21 and Eq. 22. $x$

Now, the PI controller can be implemented for FOPTD and SOPTD thermal plants with illustrative examples. 


\section{RESULTS AND DISCUSSION}

This section presents three examples to prove the proposed method. First example is a SOPTD transfer function of a shell-and-tube exchanger provided from (Vasičkaninová and Bakošová, 2016). More information about the structure can be found in (Vasičkaninová and M. Bakošová, 2012; Bakošová and J. Oravec, 2014).

Example 1: Consider the following SOPTD plant of a shell-and-tube heat exchanger where petroleum is heated by hot water passing through a copper tube.

$$
P_{1}(s, K, T, \Theta)=\frac{K}{(T s+1)^{2}} e^{-\Theta s}=\frac{53500}{(25 s+1)^{2}} e^{-1.5 s}
$$

Desired phase crossover frequency is $\omega_{g c}=0.01 \mathrm{rad} / \mathrm{sec}$ and the phase margin is $\phi_{m}=45^{\circ}$. Replacing the unknown variables in Eq. 21 and Eq. 22, the PI controller is obtained as,

$$
C_{1}(s)=-5.4968 \times 10^{-6}+\frac{1.9084 \times 10^{-7}}{s}
$$

Fig. 2 shows the Bode diagram of the SOPTD plant in Eq. 29 controlled by the PI controller in Eq. 30.

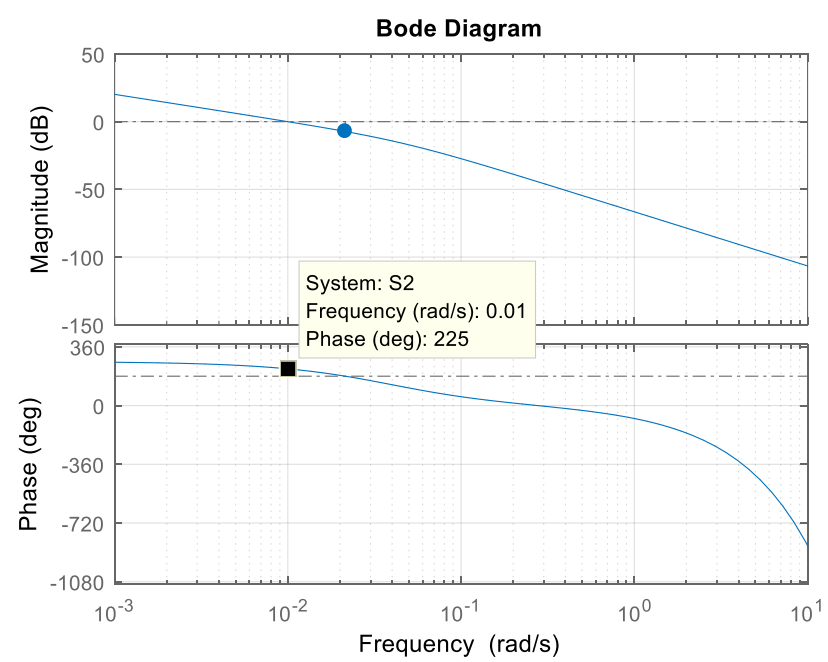

Fig. 2. Bode diagram of the SOPTD plant in Eq. 29 controlled by the PI controller in Eq. 30.

It can be seen clearly in the figure that desired phase crossover frequency and phase margin is satisfied successfully. For the stability check, Fig. 3 shows the step response of the closed loop controlled system. The PI controller obtained in this case is a non-minimum phase one as seen in Eq. 30. Therefore, the step response moves in the opposite direction at first and then, goes through the reference value. Fig. 4 illustrates the pole-zero map. 


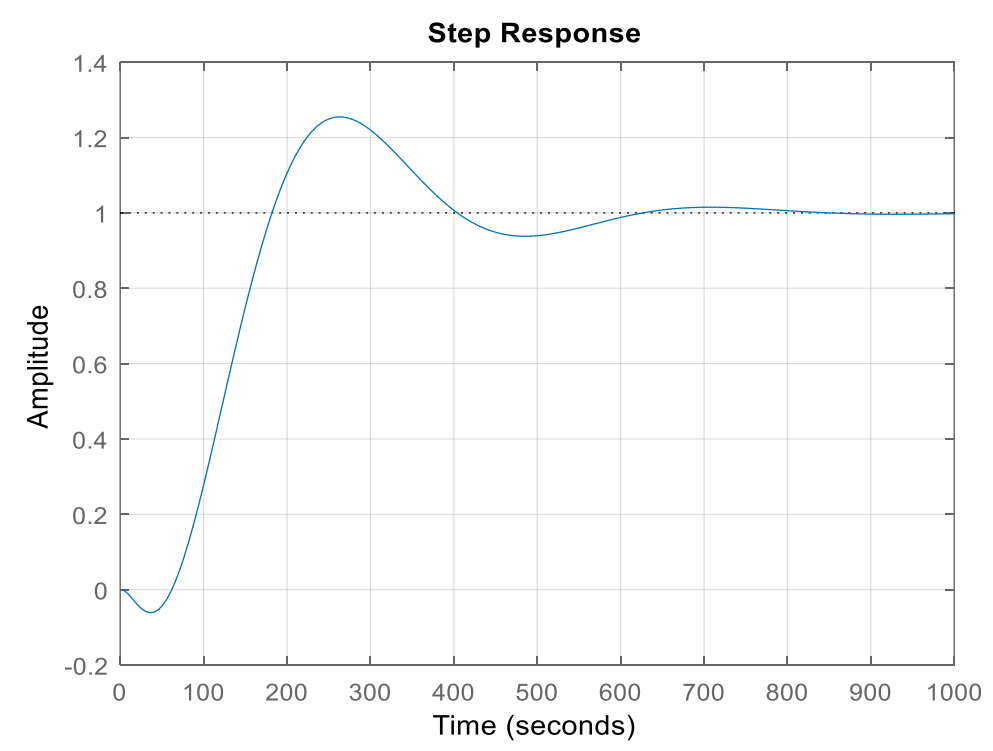

Fig. 3. Step response of the controlled system $C_{1}(s) P_{1}(s)$.

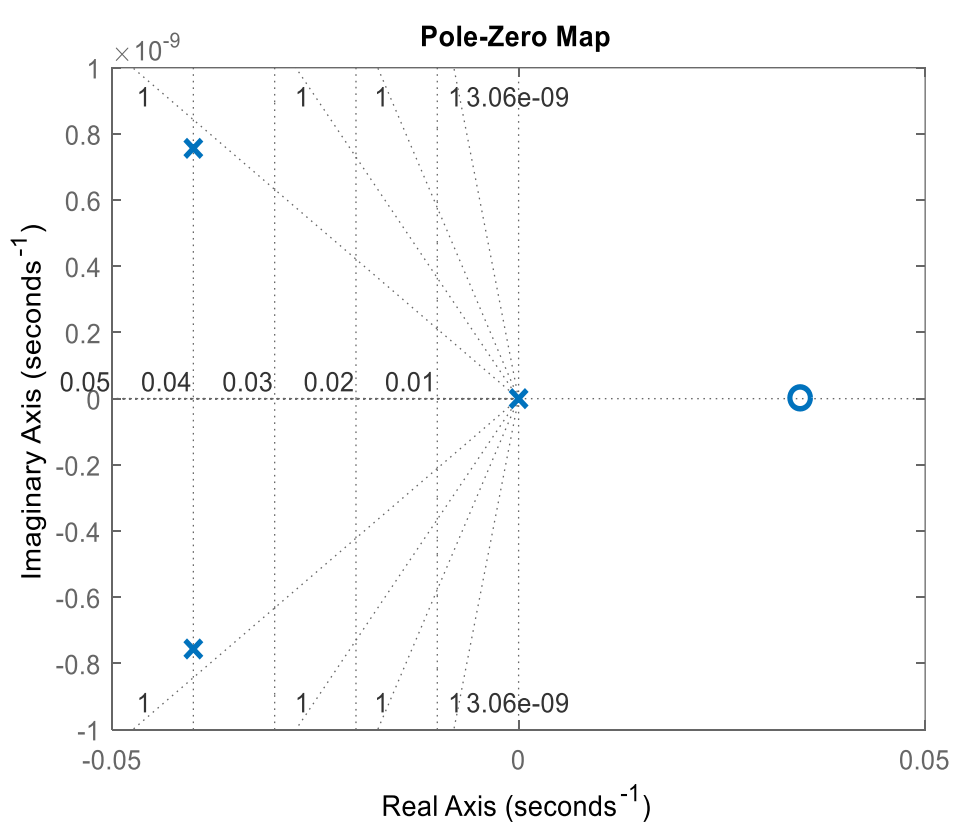

Fig. 4. Pole-zero map for the system $C_{1}(s) P_{1}(s)$.

Now, let us consider the phase crossover frequency as $\omega_{g c}=0.05 \mathrm{rad} / \mathrm{sec}$ and the phase margin as $\phi_{m}=30^{\circ}$. Then, the PI controller is obtained as,

$$
C_{2}(s)=3.5 \times 10^{-5}+\frac{1.63 \times 10^{-6}}{s}
$$

Bode diagram of the controlled system of the plant in Eq. 29 with the controller in Eq. 31 is given in Fig. 5 and step response of the closed loop system is illustrated in Fig. 6. Also the polse zero map for $C_{2}(s) P_{1}(s)$ is given in Fig. 7. Again, the frequency response of the controlled system satisfies desired phase specifications and the system is stable with the PI controller. 


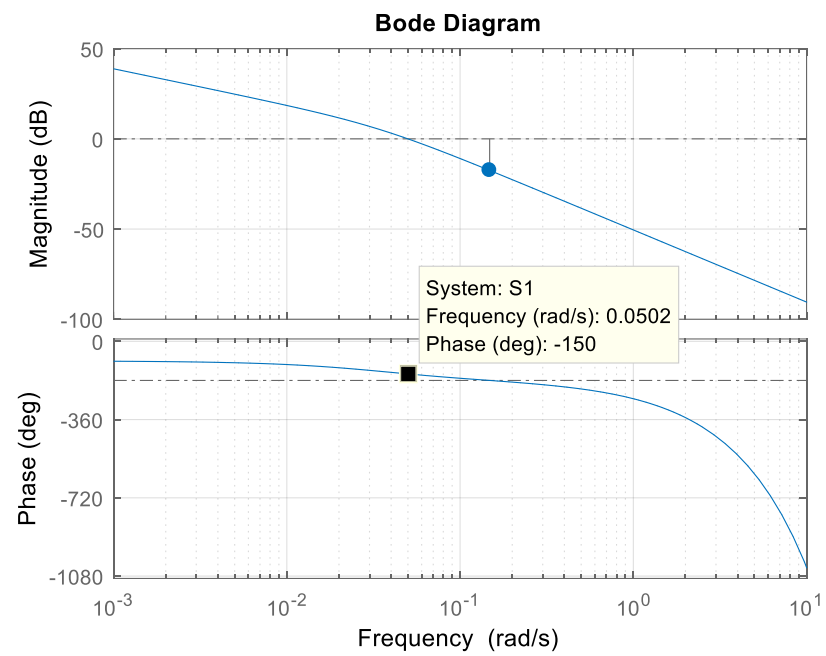

Fig. 5. Bode diagram of the SOPTD plant in Eq. 29 controlled by the PI controller in Eq. 31.

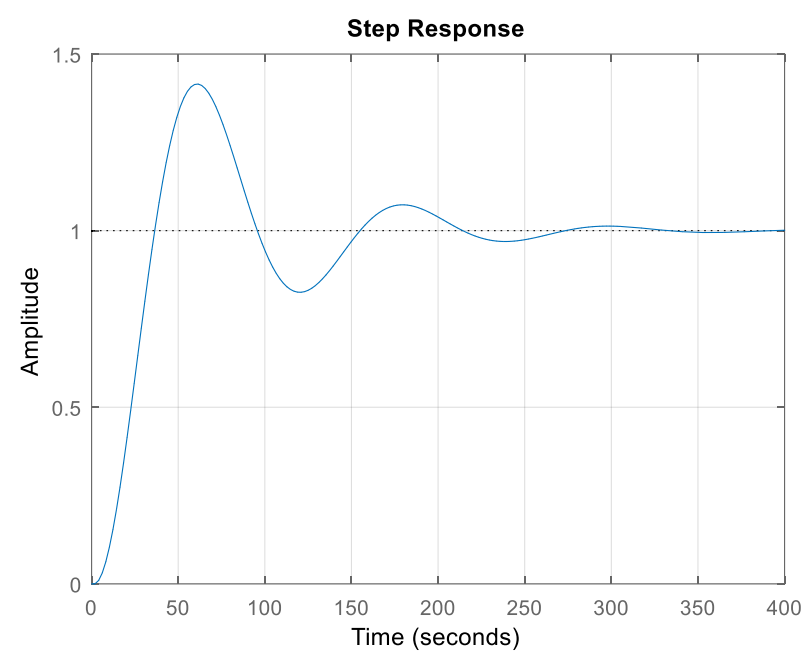

Fig. 6. Step response of the controlled system $C_{2}(s) P_{1}(s)$.

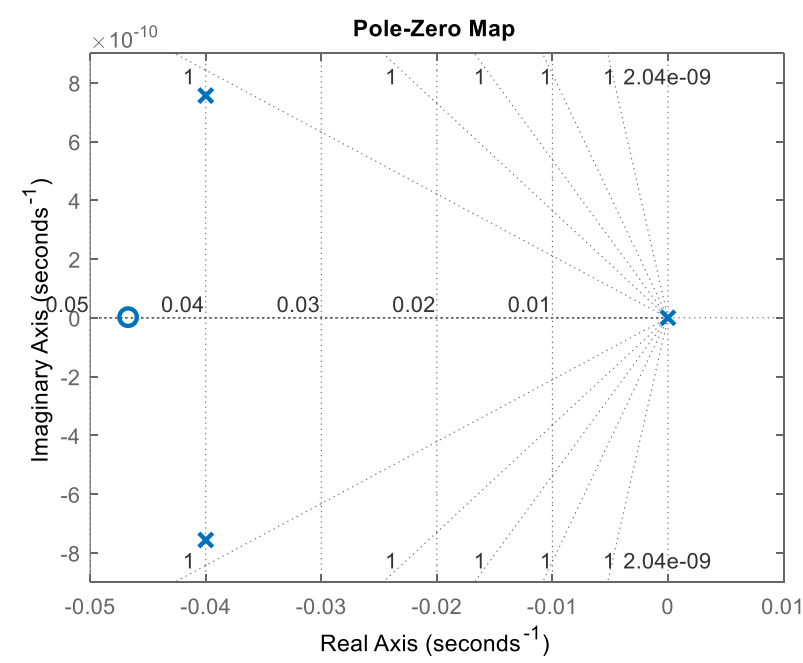

Fig. 7. Pole-zero map for the system $C_{2}(s) P_{1}(s)$.

Consequently, efficiency of the proposed method is proved on a SOPTD thermal plant. Let us consider a FOPTD thermal plant of a infrared heater. 
Example 2: Consider the FOPTD plant of a ceramic infrared heater with the nominal value of $\mathrm{K}$ in (Shekher et al., 2016).

$$
P_{2}(s)=\frac{4.08}{140 s+1} e^{-7 s}
$$

The phase crossover frequency is desired to be $\omega_{c}=0.02 \mathrm{rad} / \mathrm{sec}$ and the phase margin is desired to be $\phi_{m}=30^{\circ}$. Then following PI controller is obtained using the formulations in Eq. 11 and Eq. 12 .

$$
C_{3}(s)=0.201+\frac{0.00371}{s}
$$

Fig. 8 is the Bode plot of the plant in Eq. 32 controlled with the controller in Eq. 33. It is clear that the system has a phase margin of $30^{\circ}$ at the phase crossover frequency $\omega_{c}=0.02 \mathrm{rad} / \mathrm{sec}$. Stability of the system can be verified by the closed loop step response given in Fig. 9 and the pole-zero map in Fig. 10.

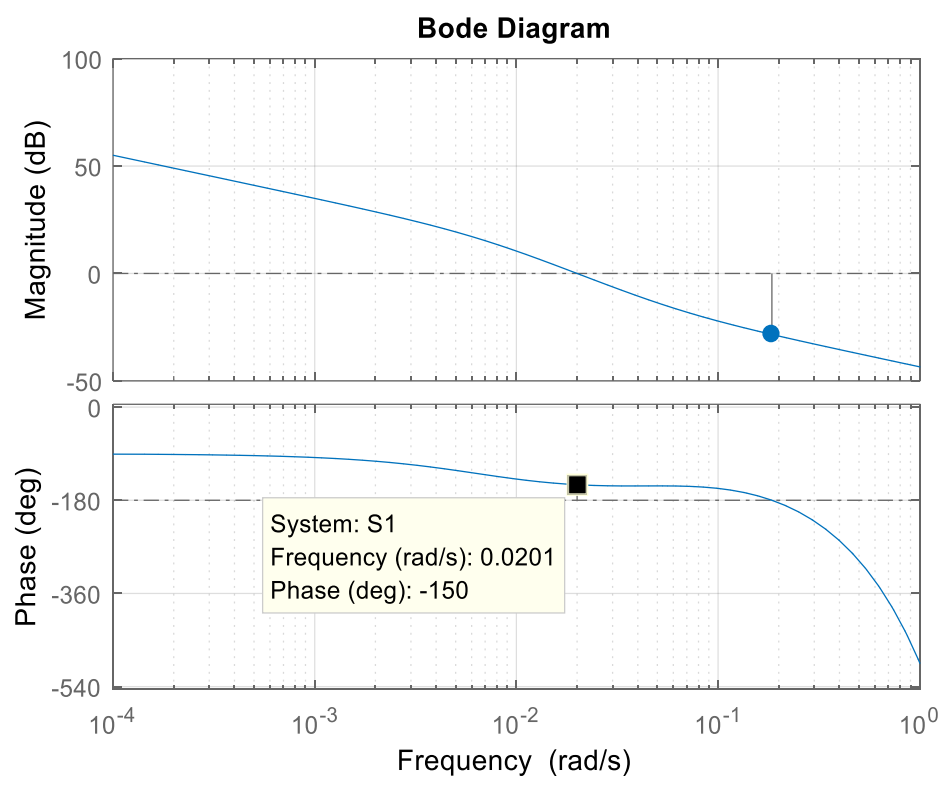

Fig.8. Bode plot of the plant in Eq. 32 controlled with the controller in Eq. 33.

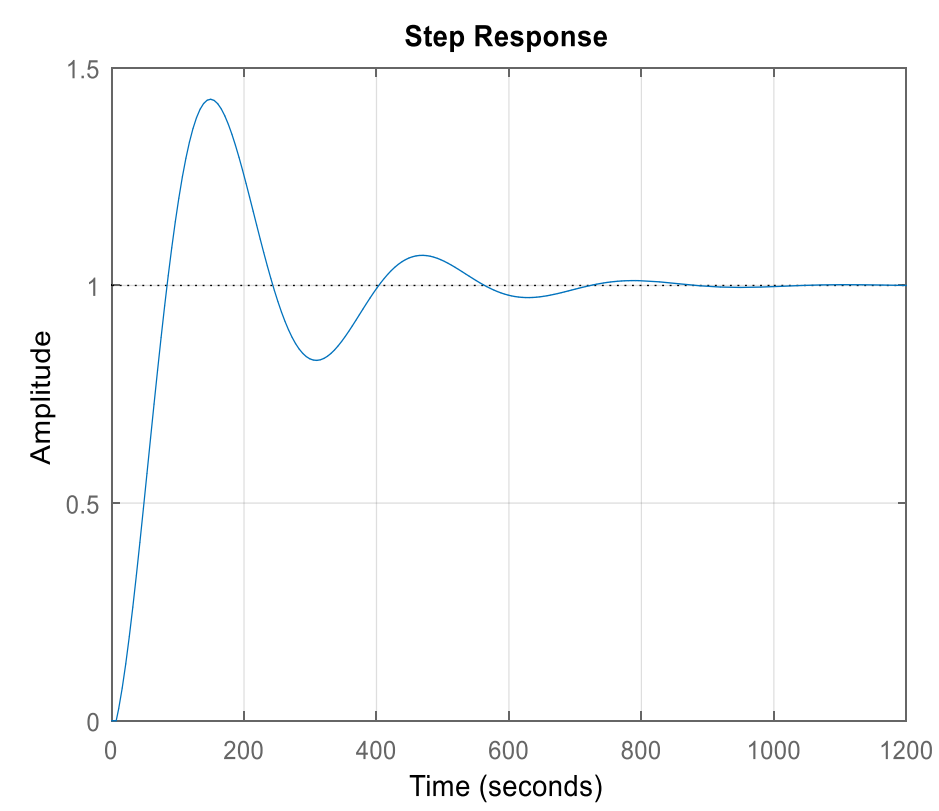

Fig. 9. Step response of the controlled system in Example 2. 


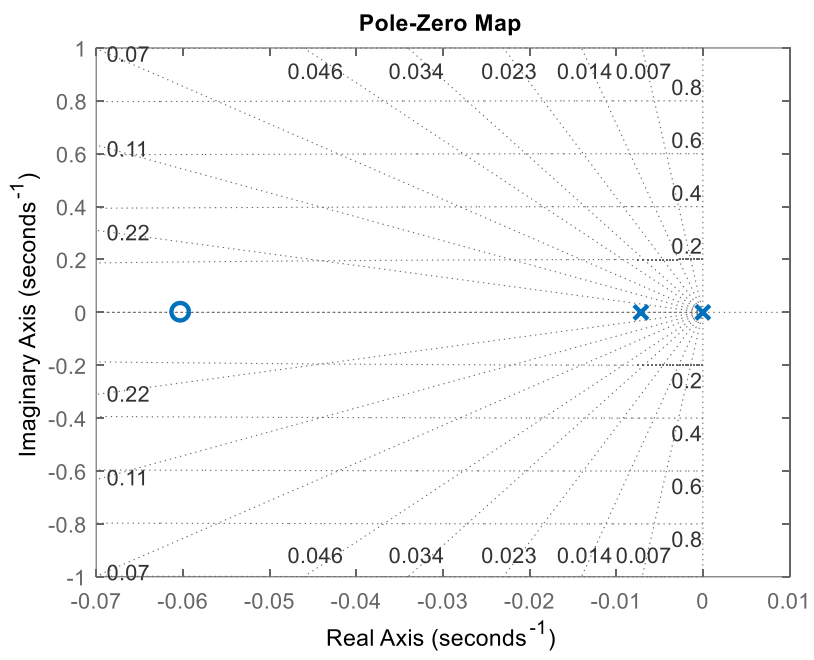

Fig. 10. Pole-zero map of the system in Example 2.

We can change the phase margin in an interval and check the performance and the stability. Table 1 lists the parameters of the PI controller found for the variations of $\phi_{m} \in\left[30^{\circ}, 60^{\circ}\right]$ with the increment steps of $5^{\circ}$ at $\omega_{c}=0.02 \mathrm{rad} / \mathrm{sec}$.

Table 1. PI controller parameters for variations of the phase margin.

\begin{tabular}{cccccccc}
\hline$\phi_{m}$ & $30^{\circ}$ & $35^{\circ}$ & $40^{\circ}$ & $45^{\circ}$ & $50^{\circ}$ & $55^{\circ}$ & $60^{\circ}$ \\
\hline$k_{p}$ & 0.23 & 0.289 & 0.346 & 0.401 & 0.452 & 0.5 & 0.545 \\
$k_{i}$ & 0.0138 & 0.0134 & 0.0128 & 0.0122 & 0.0114 & 0.0106 & 0.00968 \\
\hline
\end{tabular}

Bode diagrams and closed loop step responses of the plant in Eq. 32 with the controllers listed in Table 1 are respectively given in Fig.11 and Fig. 12. It is seen that all 7 systems are stable and satisfy desired phase specification.

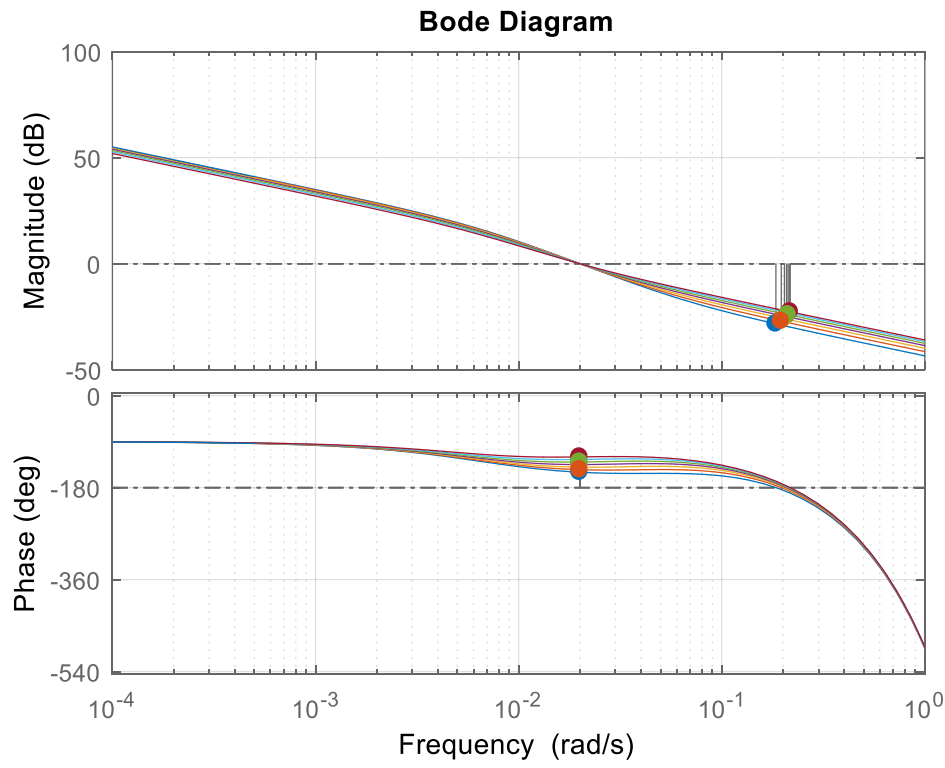

Fig. 11. Bode diagrams of the plant in Eq. 32 with the controllers in Table 1. 


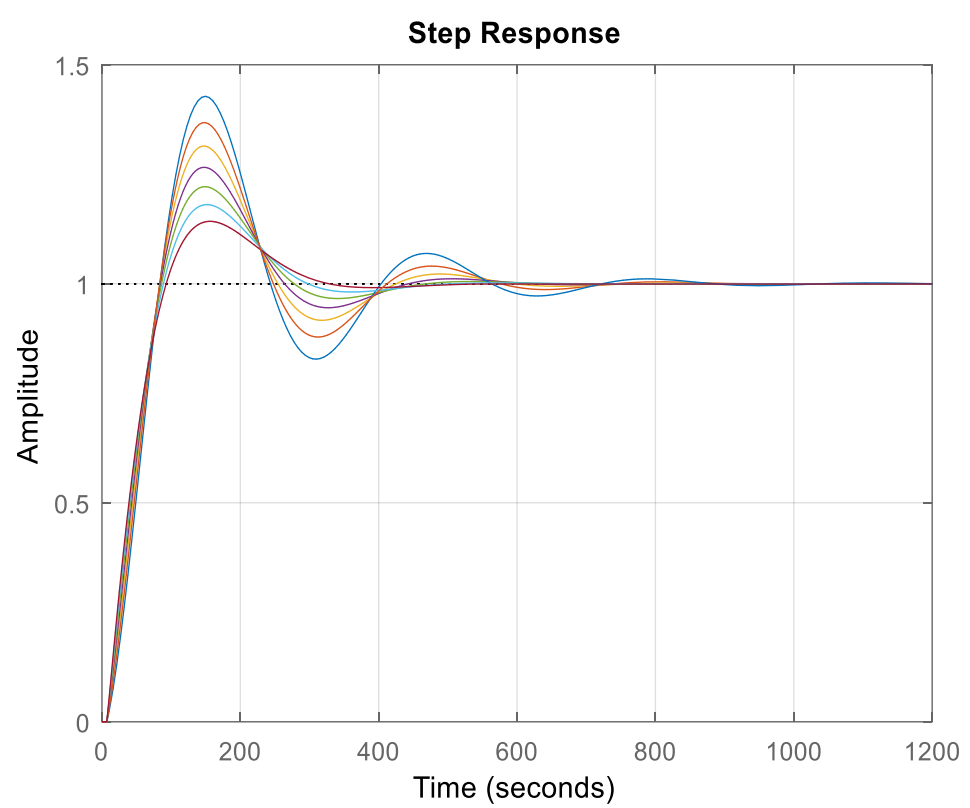

Fig. 12. Step responses of the plant in Eq. 32 with the controllers in Table 1.

\section{CONCLUSION}

Main motivation of this paper lies on PI controller design for stability and performance of thermal plants described by FOPTD and SOPTD transfer functions. PI controller is tuned considering some phase crossover frequency and phase margin requirements. Gain and phase specifications are inspired from Bode's ideal transfer function. PI controller design for both FOPTD and SOPTD plants are explicated and the results are illustratively given. The results show that the desired frequency specifications are successfully achieved. By tuning the phase margin, tolerance of the system to avoid unstability can easily be changed. Thus, the method can have direct effect on the stability of the mentioned systems. Main contribution of the method in this paper is the analytical approach to calculate the controller parameters. As well as analytical methods in the literature, optimization techniques are considerably used in frequency domain controller tuning. Advantage of the method in this paper is the direct analytical calculation formulas which bring reliability and simplicity. The method can be extended for more performance and robustness specifications in future works.

\section{REFERENCES}

Bakošová M, Oravec J, 2014. Robust model predictive control for heat exchanger network. Applied Thermal Engineering 73 (1): 924-930.

Barbosa RS, Machado JAT, Ferreira LM, 2004. Tuning of PID controllers based on Bode's ideal transfer function. Nonlinear Dynamics 38: 305-321.

Chen W, Zou C, Li X, Li L, 2017. Experimental investigation of SiC nanofluids for solar distillation system: Stability, optical properties and thermal conductivity with saline water-based fluid. International Journal of Heat and Mass Transfer 107: 264-270.

Cokmez E, Atiç S, Peker F, Kaya I, 2018. Fractional-order PI Controller Design for Integrating Processes Based on Gain and Phase Margin Specifications. IFAC-PapersOnLine 51 (4): 751-756.

Fung H, Wang Q, Lee T, 1998. PI Tuning in Terms of Gain and Phase Margins. Automatica 34 (9): 1145-1149. Gabano JD, Poinot T, 2011. Fractional modelling and identification of thermal systems, Signal Processing 91 (3): 531-541. 
He W, Xu G, Shen R, 2014. Control of temperature uniformity in the temperature chamber with centrifugal acceleration. Journal of Process Control 24 (12): 1-6.

Hernandez A, Desideri A, Gusev S, Ionescu CM, Van Den Broek M, Quoilin S, Lemort V, De Keyser R, 2017. Design and experimental validation of an adaptive control law to maximize the power generation of a smallscale waste heat recovery system. Applied Energy 203: 549-559.

Ho WK, Hang CC, Cao LS, 1995. Tuning of PID controllers based on gain and phase margin specifications. Automatica 31 (3): 497-502.

Hu K, Zhu J, Zhang W, Liu K, Lu X, 2017. Effects of evaporator superheat on system operation stability of an organic Rankine cycle. Applied Thermal Engineering 111: 793-801.

Ilyas SU, Pendyala R, Narahari M, Susin L, 2017. Stability, rheology and thermal analysis of functionalized alumina-thermal oil-based nanofluids for advanced cooling systems. Energy Conversion and Management 142: 215-229.

Jaluria Y, 2007. Design and Optimization of Thermal Systems. CRC Press, Boca Raton-USA.

Jamal A, Syahputra R, 2016. Heat Exchanger Control Based on Artificial Intelligence Approach. International Journal of Applied Engineering Research 11 (16): 9063-9069.

Kar B, Roy PJ, 2018. A Comparative Study Between Cascaded FOPI-FOPD and IOPI-IOPD Controllers Applied to a Level Control Problem in a Coupled Tank System. Control Autom Electr Syst 29 (3): 340-349.

Khayyam H, 2013. Adaptive intelligent control of vehicle air conditioning system. Applied Thermal Engineering 51 (1): 1154-1161.

Liu J, Wang F, Zhang L, Fang X, Zhang Z, 2014. Thermodynamic properties and thermal stability of ionic liquidbased nanofluids containing graphene as advanced heat transfer fluids for medium-to-high-temperature applications. Renewable Energy 63: 519-523.

Macias M, Sierociuk D, 2012. Fractional order calculus for modeling and fractional PID control of the heating process. 13th International Carpathian Control Conference, Podbanské, Slovakia,

Matušů R, Pekař L, 2017. Robust stability of thermal control systems with uncertain parameters: The graphical analysis examples. Applied Thermal Engineering 125: 1157-1163.

Miao Z, Han T, Dang J, Ju M, 2017. FOPI/PI controller parameters optimization using PSO with different performance criteria. IEEE 2nd Information Technology, Networking, Electronic and Automation Control Conference, Chengdu, China.

Onat C, Hamamci SE, Obuz S, 2012. A Practical PI Tuning Approach For Time Delay Systems. IFAC Proceedings 45 (14): 102-107.

Padhee S, 2014. Controller design for temperature control of heat exchanger system: simulation studies. WSEAS Transaction on System and Control 9: 485-491.

Pawar SN, Majumder K, Patre BM, Chile RH, 2015. Comparison of PID Controller Tuning Methods for Shell and Tube Type Heat Exchanger System. 2015 Indian Control Conference, Chennai, India.

Peralez J, Tona P, Sciarretta A, Dufour P, Nadri M, 2012. Towards model-based control of a steam Rankine process for engine waste heat recovery. 2012 IEEE Vehicle Power and Propulsion Conference, Seoul.

Powell KM, Rashid K, Ellingwood K, Tuttle J, Iverson BD, 2017. Hybrid concentrated solar thermal power systems: A review. Renewable and Sustainable Energy Reviews 80: 215-237.

Rashid ARM, Siddikhan PM, Selvakumar C, Suresh M, 2017. The performance analysis of PID controller with setpoint filter and anti-integral Windup for a FOPDT thermal process. 2017 Third International Conference on Sensing, Signal Processing and Security, Chennai, India.

Rathod MK, Banerjee J, 2013. Thermal stability of phase change materials used in latent heat energy storage systems: A review. Renewable and Sustainable Energy Reviews 18: 246-258.

Sharif MZ, Azmi WH, Redhwan AAM, Mamat R, 2016. Investigation of thermal conductivity and viscosity of Al2O3/PAG nanolubricant for application in automotive air conditioning system. International Journal of Refrigeratio 70: 93-102.

Shekher V, Gupta VS, Saroha S, 2016. Analysis of Fractional order PID controller for Ceramic Infrared Heater. International Journal of Engineering Development and Research 4 (1): 43-52. 


\section{Proportional-Integral Controller Design for Thermal Systems}

Vasičkaninová A, Bakošová M, 2012. Robust control of heat exchangers. Chemical Engineering Transactions 29: 1363-1368.

Vasičkaninová A, Bakošová M, 2016. Robust controller design for a heat exchanger using $\mathscr{H} 2, \mathscr{H} \propto \infty, \mathscr{H} 2 / \mathscr{H} \propto \infty$, and $\mu$-synthesis approaches. Acta Chimica Slovaca 9 (2): 184-193.

Y. Sun, Faucher J, Jung D, Vaisman M, McPheeters C, Sharps P, Perl E, Simon J, Steiner M, Friedman D, Lee ML, 2017. Thermal stability of GaAs solar cells for high temperature applications. IEEE 44th Photovoltaic Specialist Conference, Washington, DC, USA.

Zhao W, Qian D, Zhang S, Li S, Inganäs O, Gao F, Hou J, 2016. Fullerene-Free Polymer Solar Cells with over 11\% Efficiency and Excellent Thermal Stability. Advanced Materials 28: 4734-4739. 